\title{
The role of impaired glucose and lipid metabolism and liver enzyme abnormalities in the formation of multiple acrochordons: a case-control study
}

\section{Bozulmuş glukoz ve lipid metabolizması ve anormal karaciğer enzim düzeylerinin multipl akrokordonların oluşumundaki rolü: Bir olgu kontrol çalışması}

\author{
Melis Gonulal'10, Kenan Teker²(1) \\ ${ }^{1}$ Dept. of Dermatology, Izmir Tepecik Training and Research Hospital, Izmir, Turkey, ${ }^{2}$ Dept. of General Surgery, Izmir Tepecik Training and \\ Research Hospital, Izmir, Turkey
}

\begin{abstract}
Background Acrochordons, one of skin tumors, are protrusions of the loose fibrous tissue. In various studies, they have found to be associated with abnormal lipid profile, diabetes, cardiovascular disease, obesity, abnormal liver enzymes and genetic factors. In our case-control study, we aimed to determine possible associations of multiple acrochordons with obesity, impaired glucose and lipid metabolism, thyroid disorders, anemia and liver enzymes abnormalities.

Methods Sixty-five patients ( 32 male, 33 female) with at least 8 skin tags and age- and gender-matched 60 controls without skin tags (30 male, 30 female) were enrolled to the study. We noted patients' and controls' age, height, weight, body mass index (BMI) and detailed medical history. Locations of acrochordons were recorded for the patient group. We recorded values of fasting plasma glucose, insulin, homeostatic model assessment insulin resistance (HOMA-IR), total cholesterol, triglyceride, high-density lipoprotein (HDL), low-density lipoprotein (LDL), free T3 (fT3), free T4 (fT4), thyroid-stimulating hormone (TSH), hemoglobin, ferritin, vitamin B12, aspartate aminotransferase (AST), alanine aminotransferase (ALT), gamma-glutamyl transferase (GGT), alkaline phosphatase (ALP).

Results Our study has shown a genetic predisposition to the development of multiple skin tags $(P=0.0001)$. The mean BMI was statistically significant between the patients and controls $(P<0.0001)$. In addition, we have found that when fasting plasma glucose, AST and GGT levels increase, the possibility of the forming of multiple acrochordons also increases $(P=0.048, P=0.003, P=0.013)$. We determined that increasing of $B M I$ is a risk factor for both genders $(P=0.003, P<0.0001$, respectively). We found that elevated fasting plasma glucose, insulin, HOMA-IR, total cholesterol, triglyceride, AST, ALT and GGT levels increase possibility of the forming of multiple
\end{abstract}

Corresponding author: Melis Gonulal Dept. of Dermatology, Izmir Tepecik Training and Research Hospital, Izmir, Turkey,

Phone: +90 506888 9569, E-mail: drmelis@gmail.com

Received: 12 May 2020 Accepted: 26 June 2020

Conflict of Interest: None.

Funding: None

How to cite this article: Gonulal M, Teker K. The role of impaired glucose and lipid metabolism and liver enzyme abnormalities in the formation of multiple acrochordons: a case-control study. Mucosa 2020;3:42-51

(i) (5) This work is licensed under a Creative Commons Attribution-NonCommercial 4.0 International License. 
acrochordons in females $(P=0.037, P=0.022, P=0.013$, $P=0.03, \quad P=0.007, \quad P<0.0001, \quad P=0.015, \quad P=0.005$, respectively)

\section{Conclusion}

Our results show that multiple acrochordons may be the cutaneous signs of abnormal glucose and lipid metabolism and liver enzyme abnormalities. Thus, we suggest that clinicians should see appropriate blood tests for patients with multiple skin tags and manage them accordingly.

Key words: acrochordon, skin tag, impaired glucose metabolism, impaired lipid metabolism, liver enzyme abnormalities

\section{O̊zet}

Amaç İyi huylu deri tümörlerinden olan akrokordonlar, gevşek fibröz dokunun protrüzyonlarıdır. Akrokordonların anormal lipid profili, diyabet, kardiyovasküler hastalık, obezite, anormal karaciğer enzimleri ve genetik faktörlerle ilişkili olduğu çeşitli çalışmalarda gösterilmiştir. Çalışmamızda multipl akrokordonların obezite, bozulmuş glukoz ve lipid metabolizması, tiroid hastalıkları, anemi ve karaciğer enzim anormallikleriyle arasındaki olası bağlantıları araştırmayı amaçladık.

Yöntem Çalışmamıza en az 8 adet skin tagı olan 65 hasta (32 erkek, 33 kadın) ve yaş ile cinsiyet uyumlu, skin tagı olmayan 60 kontrol olgusu dâhil edildi. Hastaların ve kontrol grubunun yaş, boy, kilo, vücut kitle indeksi (VKI) ve ayrıntılı medikal geçmişlerini not ettik. Hasta grubunda akrokordonların yerleşim yerleri kayıt edildi. Hastaların ve kontrol grubunun açlık plazma glukoz, insülin, insülin direnci düzeyi (HOMA-IR), total kolesterol, trigliserid, yüksek ağırlıklı lipoprotein (HDL), düşük ağırlıklı lipoprotein (LDL), serbest T3 (fT3), serbest T4 (fT4), tiroid stimulan hormon (TSH), hemoglobin, ferritin, vitamin B12, aspartat aminotransferaz (AST), alanin aminotransferaz (ALT), gamma glutamil transferaz (GGT), alkalen fosfataz (ALP) ölçümlerini kayıt ettik.

Bulgular Çalışmamız sonucu multipl skin tag oluşumunda genetik eğilimin var olduğunu göstermektedir $(P=0.0001)$. Hastaların ve kontrol grubunun ortalama
VKİ değerleri arasında belirgin düzeyde anlamlılık mevcuttu $(P<0.0001)$. Ek olarak, açlık plazma glukoz, AST ve GGT düzeylerindeki artışın multipl akrokordon oluşum olasılığını arttırdığını bulduk (sırasıyla $P=0.048, P=0.003, P=0.013$ ). VKİ'ndeki artışın her iki cinsiyet için de risk oluşturduğunu tespit ettik (sırasıyla $P=0.003, P<0.0001)$. Ayrıca, açlık plazma glukoz, insülin, HOMA-IR, total kolesterol, trigliserid, AST, ALT ve GGT düzeylerindeki artışların kadın hasta grubunda multipl akrokordon oluşum olasılığını arttırdığını bulduk (sırasıyla $P=0.037, P=0.022, P=0.013$, $P=0.03, P=0.007, P<0.0001, P=0.015, P=0.005)$.

Sonuç Çalışmamızın sonuçları multipl akrokordonların anormal glukoz ve lipid metabolizması ve karaciğer enzim anormalliklerinin deri bulgusu olabileceğini göstermektedir. Bu nedenle, klinisyenlerin multipl akrokordon şikayeti ile başvuran hastalardan uygun kan testlerini istemelerini ve onları buna uygun yönetmelerini öneriyoruz.

Anahtar kelimeler: akrokordon, skin tag, bozulmus glukoz metabolizması, bozulmuş lipid metabolizması, karaciğer enzim anomalileri

\section{Introduction}

Acrochordons, one of the benign skin tumors, are protrusions of the loose fibrous tissue ranged in size from $1 \mathrm{~mm}$ to $2 \mathrm{~cm}$ in diameter. ${ }^{1-3}$ They're also called as soft fibromas or fibroadipomas or fibroepithelial polyps or skin tags that are mainly on the neck, eyelids, axillae and major flexures. ${ }^{4}$ Acrochordons have a reported incidence of 50 to $60 \%$ in the general population overall and prevalence in males and females has been reported to be equal. Multiple acrochordons have found to be associated with abnormal lipid profile, diabetes, cardiovascular disease, obesity, abnormal liver enzymes and genetic factors in some studies., ${ }^{2,3}$ On the contrary, in some studies, no relation has been detected. This study is a case-control study to determine possible association of multiple acrochordons with obesity, impaired glucose and lipid metabolism, thyroid hormones disorders, anemia and liver enzymes abnormalities.

\section{Methods}

This study was approved by the ethics committee 
of Izmir Tepecik Training and Research Hospital, 2019/14-12 with decision number. We scanned patient files admitted to the dermatology outpatient clinic of Izmir Tepecik Training and Research Hospital between October 2018 and October 2019 retrospectively. Sixty-five patients (32 male, 33 female) whose file informations were complete and age- and gender-matched 60 controls without skin tags (30 male, 30 female) were enrolled to the study. Control group was randomly selected from the same outpatient department with unrelated dermatological illness and without a known internal disease.

\section{Exclusion criteria:}

1- Age less than 18 years

2- Pregnancy, lactation, and postpartum period up to 1 year

3- Endocrinopathies

4- Inflammatory bowel diseases

5- Patients on systemic steroids $>3$ weeks, hormones, drugs or chemicals causing dyslipidemia or diabetes

6- Patients with lower than 8 skin tags (In Crook's study $^{3}$ it was specified that the person who had at least 8 skin tags had multiple acrochordons.)

We noted patients' and controls' age, height, weight, body mass index (BMI), detailed medical history (smoking, malign skin tumor in herself/himself, acrochordon in $1^{\text {st }}, 2^{\text {nd }}$ and $3^{\text {rd }}$ degree relatives, all types of malignant skin tumors in $1^{\text {st }}, 2^{\text {nd }}$ and $3^{\text {rd }}$ degree relatives, diabetes in $1^{\text {st }}, 2^{\text {nd }}$ and $3^{\text {rd }}$ degree relatives). Locations of acrochordons (neck, axillae, groin, breast, eyelids and other locations) were recorded for the patient group. Venous blood samples of participants were taken on an empty stomach. We recorded values of fasting plasma glucose, fasting plasma insulin, homeostatic model assessment insulin resistance (HOMA-IR), total cholesterol, triglyceride, high-density lipoprotein (HDL), low-density lipoprotein (LDL), free T3 (fT3), free T4 (fT4), thyroid-stimulating hormone (TSH), hemoglobin, ferritin, vitamin B12, aspartate aminotransferase (AST), alanine aminotransferase (ALT), gamma-glutamyl transferase (GGT), alkaline phosphatase (ALP).

\section{Statistical analysis}

Statistical analysis was performed with SPSS Version 17.0 statistic software package. Different variables were investigated with analytical methods if they were suitable for normal distribution (Kolmogorov-Smirnov/Shapiro-Wilk tests). In descriptive analysis, parameters were written as frequency, percentage, mean, standard deviation. Pearson's chi-squared test and Fisher's exact test were used in comparing categorical data between groups. We used independent samples t-test for metric and normally distributed variables when we compared independent samples. Mann-Whitney U-test was used when non-normally distributed variables were compared. $P$ values of less than 0.05 were regarded as statistically significant.

\section{Results}

Among the total sample of 125, 33 females (26.4\%) and 32 males (25.6\%) were patients with acrochordon, 30 females (\%24) and 30 males (\%24) were controls. The mean age of patients was $47.74 \pm 12.08(\min 22$, $\max 76)$ and the mean age of controls was $44.22 \pm$ $11.51(\min 22, \max 68$ ). The difference between the mean age of the patients and controls wasn't statistically significant $(P=0.098)$.

Forty-four cases and 16 controls had skin tags in their relatives. The relationships between cases and controls and also separately between male and female groups about skin tag in relatives, malignant skin tumor in himself/herself/relatives, diabetes in relatives and smoking were shown in tables 1 and 2 .

We determined acrochordons on neck in 63 patients (96.92\%) (31 female, 32 male), on axillae in 42 patients (64.61\%) (25 female, 17 male), on breast in 14 patients $(21.53 \%)$ ( 13 female, 1 male), on groin in 12 patients (18.46\%) ( 8 female, 4 male), on eyelids in 7 patients (10.76\%) (3 female, 4 male). In addition, we found one skin tag on leg, one on arm, four skin tags on back in male cases, one acrochordon on arm, one on shoulder, one on hairy skin, one on back, one on face, one on genital area in female cases.

The mean BMI in patients was $29.36 \pm 5.85 \mathrm{~kg} / \mathrm{m}^{2}$ (min 
$\left.17.90 \mathrm{~kg} / \mathrm{m}^{2}, \max 47 \mathrm{~kg} / \mathrm{m}^{2}\right)$, in controls was $25.59 \pm$ $3.7 \mathrm{~kg} / \mathrm{m}^{2}$ (min $17.7 \mathrm{~kg} / \mathrm{m}^{2}$, $\left.\max 33.2 \mathrm{~kg} / \mathrm{m}^{2}\right) .27$ male cases and 27 female cases were obese. The mean BMI in female patients was $29.51 \pm 5.88 \mathrm{~kg} / \mathrm{m}^{2}(\min 17.9 \mathrm{~kg} /$ $\mathrm{m}^{2}$, $\max 42.6 \mathrm{~kg} / \mathrm{m}^{2}$ ) and in male patients was $29.21 \pm$ $5.91 \mathrm{~kg} / \mathrm{m}^{2}\left(\min 19.8 \mathrm{~kg} / \mathrm{m}^{2}, \max 47 \mathrm{~kg} / \mathrm{m}^{2}\right)$ (Table 3-5).

Table 1. Comparison of medical history between all cases and controls

\begin{tabular}{|c|c|c|c|c|c|}
\hline \multirow{2}{*}{ Parameters } & \multicolumn{2}{|c|}{$\begin{array}{c}\text { Case }(\%) \\
(n=65)\end{array}$} & \multicolumn{2}{|c|}{$\begin{array}{c}\text { Control (\%) } \\
(n=60)\end{array}$} & \multirow[t]{2}{*}{$P$} \\
\hline & Yes & No & Yes & No & \\
\hline Skin tag in relatives & $44(67.7)$ & $21(32.3)$ & $16(26.7)$ & $44(73.3)$ & 0.0001 * \\
\hline $\begin{array}{l}\text { Malignant skin tumors } \\
\text { in relatives }\end{array}$ & $3(4.6)$ & $62(95.4)$ & $3(5.0)$ & $57(95.0)$ & 1.000 \\
\hline Diabetes in relatives & $24(36.9)$ & $41(63.1)$ & $27(45.0)$ & $33(55.0)$ & 0.359 \\
\hline $\begin{array}{l}\text { Malignant skin tumors } \\
\text { in himself/herself }\end{array}$ & $2(3.1)$ & $63(96.9)$ & $0(0)$ & $60(100)$ & 0.497 \\
\hline Smoking & $21(32.3)$ & $44(67.7)$ & $21(35.0)$ & $39(65.0)$ & 0.750 \\
\hline
\end{tabular}

${ }^{*}$ Values are presented as numbers and percentage. $\mathrm{p} \leq 0.05$

Table 2. Comparisons of medical history between cases and controls in men and women separately

\begin{tabular}{|c|c|c|c|c|c|c|}
\hline \multirow{2}{*}{ Parameters } & \multicolumn{2}{|c|}{ Male } & \multirow{2}{*}{$P$} & \multicolumn{2}{|c|}{ Female } & \multirow{2}{*}{$P$} \\
\hline & Case (\%) & Control (\%) & & Case (\%) & Control (\%) & \\
\hline Skin tag in relatives & $18(75.0)$ & $6(25.0)$ & $0.003 *$ & $26(72.2)$ & $10(27.8)$ & 0.0001 * \\
\hline $\begin{array}{l}\text { Malignant skin tumors } \\
\text { in relatives }\end{array}$ & $2(50.0)$ & $2(50.0)$ & 0.947 & $1(50.0)$ & $1(50.0)$ & 0.945 \\
\hline Diabetes in relatives & $11(45.8)$ & $13(54.2)$ & 0.469 & $13(48.1)$ & $14(51.9)$ & 0.560 \\
\hline $\begin{array}{l}\text { Malignant skin tumors } \\
\text { in himself/herself }\end{array}$ & $1(100)$ & $0(0)$ & 0.329 & $1(100)$ & $0(0)$ & 0.336 \\
\hline Smoking & $12(54.5)$ & $10(45.5)$ & 0.732 & $9(45.0)$ & $11(55.0)$ & 0.424 \\
\hline
\end{tabular}

*Values are presented as numbers and percentage. $\mathrm{p} \leq 0.05$

All these groups were overweight. The relationships were shown in tables 3-5.

All comparisons between cases and controls about fasting plasma glucose, fasting plasma insulin, HOMA-IR, total cholesterol, triglyceride, HDL, LDL, fT3, fT4, TSH, hemoglobin, ferritin, vitamin B12, AST, ALT,
GGT, ALP were shown in tables 3-5.

\section{Discussion}

While some people have a small number of skin tags, some people have many acrochordons. This topic arises curiosity in researchers, therefore studies are 
made about this subject, but still, more definitive data couldn't been achieved because there are limited studies searching relationships between acrochordons and internal diseases. Unlike other studies, we wanted to focus on patients with multiple skin tags.
In Rasi et al.'s study ${ }^{1}$, forty-six patients (44.23\%) had a history of skin tag in other family members. Positive family history of diabetes was found in 32 patients $(30.76 \%)$ while 16 patients $(15.38 \%)$ were already diabetic and under treatment. Similar results

Table 3. Comparison of laboratory findings between cases and controls

\begin{tabular}{|c|c|c|c|}
\hline Parameters & Case (mean \pm SD) & Control $($ mean \pm SD) & $\boldsymbol{P}$ \\
\hline BMI (kg/m2) & $29.36 \pm 5.85$ & $25.59 \pm 3.70$ & $<0.0001 *$ \\
\hline Fasting plasma glucose (mg/dL) & $102.02 \pm 33.00$ & $93.21 \pm 12.34$ & $0.048^{*}$ \\
\hline Fasting plasma insulin (mU/L) & $15.91 \pm 11.18$ & $11.51 \pm 18.71$ & 0.110 \\
\hline HOMA-IR & $3.98 \pm 3.39$ & $2.73 \pm 5.10$ & 0.100 \\
\hline Total cholesterol (mg/dL) & $216.94 \pm 50.37$ & $203.58 \pm 43.48$ & 0.110 \\
\hline Triglyceride (mg/dL) & $144.41 \pm 83.97$ & $121.70 \pm 75.45$ & 0.110 \\
\hline HDL (mg/dL) & $51.06 \pm 18.79$ & $48.75 \pm 10.12$ & 0.400 \\
\hline LDL (mg/dL) & $137.52 \pm 45.66$ & $131.96 \pm 41.66$ & 0.480 \\
\hline fT3 (ng/L) & $3.66 \pm 0.74$ & $3.49 \pm 0.48$ & 0.140 \\
\hline fT4 (ng/L) & $0.90 \pm 0.23$ & $0.84 \pm 0.28$ & 0.170 \\
\hline TSH (mIU/L) & $1.95 \pm 1.38$ & $1.98 \pm 1.15$ & 0.920 \\
\hline Hemoglobin (gr/dL) & $13.80 \pm 1.70$ & $13.95 \pm 1.60$ & 0.620 \\
\hline Ferritin $(\mu \mathrm{g} / \mathrm{L})$ & $52.00 \pm 52.25$ & $61.86 \pm 56.49$ & 0.310 \\
\hline Vitamin B12 (pg/mL) & $228.26 \pm 88.77$ & $237.44 \pm 199.05$ & 0.730 \\
\hline AST (U/L) & $24.42 \pm 7.46$ & $20.68 \pm 6.37$ & $0.003 *$ \\
\hline $\operatorname{ALT}(\mathbf{U} / \mathbf{L})$ & $28.12 \pm 15.34$ & $23.11 \pm 13.97$ & 0.059 \\
\hline GGT (U/L) & $30.46 \pm 21.73$ & $22.41 \pm 11.96$ & $0.013 *$ \\
\hline $\operatorname{ALP}(\mathbf{U} / \mathbf{L})$ & $64.09 \pm 23.39$ & $66.21 \pm 22.23$ & 0.600 \\
\hline
\end{tabular}

*Values are presented as mean \pm standard deviation. $\mathrm{p} \leq 0.05$

BMI, body mass index; HOMA-IR, insulin resistance; HDL, high-density lipoprotein (HDL); LDL, low-density lipoprotein; fT3, free T3; fT4, free T4; TSH, thyroid-stimulating hormone; AST, aspartate aminotransferase; ALT, alanine aminotransferase; GGT, gamma-glutamyl transferase; ALP, alkaline phosphatase. 
Table 4. Comparison of laboratory findings between cases and controls in men

\begin{tabular}{|c|c|c|c|}
\hline Parameters & Case $($ mean $\pm \mathrm{SD})$ & Control $($ mean \pm SD) & $\boldsymbol{P}$ \\
\hline BMI (kg/m2) & $29.21 \pm 5.91$ & $25.47 \pm 2.90$ & $0.003 *$ \\
\hline Fasting plasma glucose (mg/dL) & $105.84 \pm 45.51$ & $94.36 \pm 13.38$ & 0.180 \\
\hline Fasting plasma insulin (mU/L) & $19.25 \pm 13.21$ & $15.27 \pm 24.57$ & 0.420 \\
\hline HOMA-IR & $5.04 \pm 4.22$ & $3.77 \pm 6.83$ & 0.370 \\
\hline Total cholesterol (mg/dL) & $208.14 \pm 50.46$ & $207.06 \pm 47.09$ & 0.930 \\
\hline Triglyceride $(\mathrm{mg} / \mathrm{dL})$ & $142.49 \pm 83.57$ & $145.36 \pm 91.06$ & 0.890 \\
\hline HDL (mg/dL) & $44.81 \pm 6.97$ & $46.46 \pm 7.89$ & 0.380 \\
\hline LDL (mg/dL) & $136.59 \pm 41.93$ & $136.50 \pm 46.68$ & 0.990 \\
\hline fT3 (ng/L) & $3.77 \pm 0.93$ & $3.65 \pm 0.37$ & 0.540 \\
\hline fT4 (ng/L) & $0.85 \pm 0.15$ & $0.81 \pm 0.09$ & 0.280 \\
\hline TSH (mIU/L) & $1.91 \pm 1.51$ & $1.96 \pm 1.46$ & 0.880 \\
\hline Hemoglobin (gr/dL) & $15.02 \pm 0.91$ & $14.94 \pm 10.00$ & 0.730 \\
\hline Ferritin $(\mu \mathrm{g} / \mathrm{L})$ & $73.99 \pm 54.60$ & $90.49 \pm 57.90$ & 0.250 \\
\hline Vitamin B12 (pg/mL) & $222.34 \pm 88.93$ & $264.48 \pm 265.60$ & 0.410 \\
\hline AST (U/L) & $24.02 \pm 8.51$ & $22.53 \pm 6.10$ & 0.430 \\
\hline $\operatorname{ALT}(\mathbf{U} / \mathbf{L})$ & $29.90 \pm 18.78$ & $26.93 \pm 15.31$ & 0.490 \\
\hline GGT (U/L) & $30.53 \pm 25.45$ & $25.63 \pm 11.81$ & 0.340 \\
\hline $\operatorname{ALP}(\mathrm{U} / \mathrm{L})$ & $64.84 \pm 19.65$ & $71.00 \pm 24.60$ & 0.270 \\
\hline
\end{tabular}

*Values are presented as mean \pm standard deviation. $\mathrm{p} \leq 0.05$

BMI, body mass index; HOMA-IR, insulin resistance; HDL, high-density lipoprotein (HDL); LDL, low-density lipoprotein; fT3, free T3; fT4, free T4; TSH, thyroid-stimulating hormone; AST, aspartate aminotransferase; ALT, alanine aminotransferase; GGT, gamma-glutamyl transferase; ALP, alkaline phosphatase. 
Table 5. Comparison of laboratory findings between cases and controls in women

\begin{tabular}{|c|c|c|c|}
\hline Parameters & Case (mean \pm SD) & Control (mean $\pm \mathrm{SD})$ & $\boldsymbol{P}$ \\
\hline BMI (kg/m2) & $29.51 \pm 5.88$ & $25.71 \pm 4.23$ & $<0.0001^{*}$ \\
\hline Fasting plasma glucose (mg/dL) & $98.33 \pm 11.94$ & $92.06 \pm 11.32$ & $0.037^{*}$ \\
\hline Fasting plasma insulin (mU/L) & $12.67 \pm 7.67$ & $7.75 \pm 8.92$ & $0.022 *$ \\
\hline HOMA-IR & $2.94 \pm 1.89$ & $1.69 \pm 1.98$ & $0.013 *$ \\
\hline Total cholesterol (mg/dL) & $225.48 \pm 49.55$ & $200.10 \pm 40.05$ & $0.030^{*}$ \\
\hline Triglyceride (mg/dL) & $146.27 \pm 85.61$ & $98.03 \pm 46.19$ & $0.007^{*}$ \\
\hline HDL (mg/dL) & $57.11 \pm 24.13$ & $51.03 \pm 11.63$ & 0.210 \\
\hline LDL (mg/dL) & $138.42 \pm 49.65$ & $127.43 \pm 36.20$ & 0.320 \\
\hline fT3 (ng/L) & $3.56 \pm 0.49$ & $3.33 \pm 0.53$ & 0.090 \\
\hline fT4 (ng/L) & $0.95 \pm 0.28$ & $0.86 \pm 0.39$ & 0.300 \\
\hline TSH (mIU/L) & $2.00 \pm 1.26$ & $1.99 \pm 0.75$ & 0.970 \\
\hline Hemoglobin (gr/dL) & $12.61 \pm 1.42$ & $12.95 \pm 1.47$ & 0.350 \\
\hline Ferritin $(\mu \mathrm{g} / \mathrm{L})$ & $30.67 \pm 40.25$ & $33.22 \pm 38.00$ & 0.790 \\
\hline Vitamin B12 (pg/mL) & $234.01 \pm 89.61$ & $210.40 \pm 92.49$ & 0.300 \\
\hline $\operatorname{AST}(\mathrm{U} / \mathrm{L})$ & $24.81 \pm 6.4$ & $18.83 \pm 6.19$ & $<0.0001^{*}$ \\
\hline $\operatorname{ALT}(\mathbf{U} / \mathrm{L})$ & $26.39 \pm 11.08$ & $19.30 \pm 11.51$ & $0.015^{*}$ \\
\hline GGT (U/L) & $30.39 \pm 17.81$ & $19.20 \pm 11.41$ & $0.005^{*}$ \\
\hline $\operatorname{ALP}(\mathbf{U} / \mathbf{L})$ & $63.36 \pm 26.8$ & $61.43 \pm 18.79$ & 0.740 \\
\hline
\end{tabular}

*Values are presented as mean \pm standard deviation. $\mathrm{p} \leq 0.05$

BMI, body mass index; HOMA-IR, insulin resistance; HDL, high-density lipoprotein (HDL); LDL, low-density lipoprotein; fT3, free T3; fT4, free T4; TSH, thyroid-stimulating hormone; AST, aspartate aminotransferase; ALT, alanine aminotransferase; GGT, gamma-glutamyl transferase; ALP, alkaline phosphatase. 
were reported in the study of El-Zawahry et al. ${ }^{5}$ In our research, 44 patients $(67.7 \%)$ have relatives with skin tags and 24 patients (36.9\%) have relatives with diabetes. There was a significant correlation between skin tags and skin tag in relatives, therefore skin tags are more likely to be seen in persons who have relatives with acrochordons. According to this result, we can say that genetic predisposition is effective in the formation of acrochordons. We don't think that smoking effects the formation of skin tags because there wasn't any significant correlation between groups.

In the study of Rasi et al., ${ }^{1}$ frequency of the locations of skin tags are listed as neck, axillae, breast, groin and face. These results were compatible with data of our research. In the study of Tripathy et al., ${ }^{6}$ acrochordons were determined in order of frequency on neck, axillae, eyelid and trunk. In the study of Agarwal and Nigam, the frequency of location of skin tags are reported as axillae, trunk, neck, eyelid, face respectively.

Skin tag commonly develops in individuals with obesity and their prevalence correlated positively with the severity of the obesity. ${ }^{8,9}$ In the study of Idris and Sunitha ${ }^{4}$, there was a significant correlation between BMI and acrochordons. In Rasi et al.'s study ${ }^{1}$, there wasn't a positive correlation between the number of skin tags and BMI, but in the study of Tripathy et al., ${ }^{6}$ there was a significant relationship between acrochordons and BMI. El-Zawahry et al., ${ }^{5}$ determined that acrochordons were seen more in obese patients than in non-obese patients. In the research of Safoury et al., ${ }^{10} \mathrm{BMI}$ was significantly higher in skin tag patients compared to controls, likewise in the study of Demir S. and Demir Y. ${ }^{11}$ In our study, we found that BMI values in the cases were significantly higher than in the control group. According to this result, when we evaluated separately male and female groups, we achieved again similar results which should be considered carefully since both cases and controls were overweight. We think that weight gain increases the risk of formation of multiple skin tags, obesity alone isn't a risk factor. Persons should be careful not to gain excess weight if they don't want to have multiple acrochordons.

In Tripathy et al.'s study ${ }^{6}$ significant relationship wasn't determined between skin tags and fasting plasma glucose levels. In our research, when we evaluated all cases and controls, there was a significant relationship between acrochordons and fasting plasma glucose, however in men we didn't find the similar result but only in female group we determined that fasting plasma glucose levels in the female cases were significant higher than in female controls.

Skin tags have also been associated with hyperinsulinemia. ${ }^{12}$ Multiple skin tags were found by Sudy et al., to be more sensitive than acanthosis nigricans in identifying patients with hyperinsulinemia and insulin resistance. ${ }^{13}$ In the study of El-Zawahry et al., ${ }^{5}$ skin tags were higher among diabetic (60.5\%) than among non-diabetic (39.5\%) participants; which was statistically significant. In the research of Safoury et al., ${ }^{10}$ fasting glucose, insulin levels, insulin resistance were significantly higher in skin tag patients compared to controls. Erdogan et al. ${ }^{14}$ found that patients with multiple skin tags were more likely to be insulin resistant by a raised HOMA-IR. In the study of Demir and Demir, no distinct relationship between the presence of carbohydrate metabolism impairment and the number or localization of acrochordons was found. In our study, we have found that probability of formation of skin tags is increasing while fasting plasma insulin is increasing in female group. HOMAIR was higher than 2.5 both in cases and controls and there wasn't a significant relationship between two groups. We found a significant relationship between HOMA-IR and skin tags in the female group. If we appreciate all results in the literature including our work, high values of fasting plasma glucose, fasting plasma insulin and HOMA-IR may increase the risk of acrochordons, but additional studies are needed.

There have been data in the literature about the relationship between acrochordon and atherogenic lipid profiles. ${ }^{4}$ In the study of Idris and Sunitha ${ }^{4}$, there was a positively significant relationship between the level of total cholesterol and skin tag $(P=0.001)$. Erdogan et al. ${ }^{14}$ also found serum total cholesterol levels higher in the skin tag group than the control group. Tamega 
et al., ${ }^{15}$ reported higher serum triglyceride levels in the skin tag group than the control group. In the study of Tripathy et al. ${ }^{6}$ the lipid profile status showed significantly higher total cholesterol and triglyceride levels and lower HDL levels in cases compared to controls. Gorpelioglu et al., ${ }^{16}$ found significantly higher total cholesterol and LDL levels in cases compared to controls. In the research of Safoury et al., ${ }^{10}$ cholesterol, triglycerides and HDL levels were significantly higher in skin tag patients compared to controls. In our study, serum total cholesterol, triglyceride, HDL, LDL levels were higher in case group than in control group but there weren't significant correlations between these two groups. When we evaluated only male groups, we achieved similar results. In female groups, it can be said that there were significant relationships only between acrochordons and the levels of total cholesterol and triglyceride. We think that high serum values of atherogenic lipids may create a risk for acrochordons.

To our knowledge, a possible relationship between acrochordons and TSH, fT3, fT4, hemoglobin, vitamin B12, ferritin levels has not been investigated in the previous studies. We didn't find any significant relationships between these laboratory tests and acrochordons. Studies in larger groups may give different results. For now, according to these results, we think that the levels of TSH, fT3, fT4, hemoglobin, vitamin B12, ferritin don't create a risk for the formation of skin tags.

When we investigated the literature about relationship between serum AST, ALT, GGT, ALP levels and skin tags, we found the study of Senel et al. ${ }^{2}$ They found significantly higher serum AST, ALT, GGT and ALP values in the patients than those in the controls. We found in our research that serum AST and GGT levels were significantly higher in patients than in controls. Additionally, in females, serum AST, ALT, GGT levels were significantly higher in patients than in controls. Based on these results we can say that multiple acrochordons may be indicative for abnormal liver enzymes.

There were some limitations of our study. We inspe- cted patients' files retrospectively and included only patients whose data were complete. In addition, we achieved to record only fasting plasma glucose and insulin of patients. If we could reach other parameters about diabetes like two hour glucose tolerance test, we could have interpreted the effects of diabetes in the formation of acrochordons.

In conclusion, our results show that multiple acrochordons may be the cutaneous signs of abnormal glucose and lipid metabolism and liver enzyme abnormalities. Thus, we suggest that clinicians should see appropriate blood tests for patients with multiple skin tags and manage them accordingly.

\section{References}

1. Rasi A, Soltani-Arabshahi R, Shahbazi N. Skin tag as a cutaneous marker for impaired carbohydrate metabolism: a case-control study. Int J Dermatol 2007;46:1155-9.

2. Senel E, Salmanoglu M, Solmazgul E, Bercik Inal B. Acrochordons as a cutaneous sign of impaired carbohydrate metabolism, hyperlipidemia, liver enzyme abnormalities and hypertension: a case-control study. J Eur Acad Dermatol Venereol 2011.

3. Crook M. Skin tags: a useful clinical sign for insulin resistance. Eur J Dermatol 2012;22:5-6.

4. Idris S. Sunitha S. Assessment of BMI, serum leptin levels and lipid profile in patients with skin tags. J Clin Diagn Res 2014;8:1-3.

5. Khaled M El-Zawahry, Mohamed A.R. Abdallah, Heba E Elmahdy. Study of the possible relationship between skin tags and obesity in Egypt. Egypt J Dermatol Venereol 2013;33:18-21.

6. Tripathy T, Singh BSTP, Kar BR. Association of skin tag with metabolic syndrome and its components: a case-control study from Eastern India. Indian Dermatol Online J 2019;10:284-7.

7. Agarwal JK, Nigam PK. Acrochordon: a cutaneous sign of carbohydrate intolerance. Australas J Dermatol 1987;28:132-3.

8. Sari R, Akman A, Alpsoy E, Balchi MK. The metabolic profile in patients with skin tags. Clin Exp Med 2010;10:193-7.

9. Gracia Hidalgo L, Orozco-Topete R, Gonzalez-Barranco J, et al. Dermatoses in 156 obese adults. Obes Res 1999;7:299-302.

10. El Safoury OS, Abdel Hay RM, Fawzy MM, et al. Skin tags, leptin, metabolic syndrome and change 
of the life style. Indian J Dermatol Venereol Leprol 2011;77:577-80.

11. Demir S, Demir Y. Acrochordon and impaired carbohydrate metabolism. Acta Diabetol 2002;39:57-59.

12. Saraiya A, Al-Shoha A, Brodell RT. Hyperinsulinemia associated with acanthosis nigricans, finger pebbles, acrochordons and the sign of Leser-Trelat. Endocr Pract 2013;19:522-5.

13. Sudy E, Urbina F, Maliqueo M, Sir T. Screening of glucose/insulin metabolic alterations in men with multiple skin tags on the neck. J Dtsch Dermatol Ges 2008;6:852-5.

14. Erdogan BS, Aktan S, Rota S, Ergin S, Evliyaoğlu D. Skin tags and atherosclerotic risk factors. J Dermatol 2005;32:371-5.

15. Tamega Ade A, Aranha AM, Guiotoku MM, et al. Association between skin tags and insulin resistance. An Bras Dermatol 2010;85:25-31.

16. Gorpelioglu C, Erdal E, Ardicoglu Y, et al. Serum leptin, atherogenic lipids and glucose levels in patients with skin tags. Indian J Dermatol 2009;54:20-2. 